\title{
Idiosyncratic responses of seagrass phenolic production following sea urchin grazing
}

\author{
LaTina Steele ${ }^{1,2,3, *}$, John F. Valentine ${ }^{1,2}$ \\ ${ }^{1}$ Dauphin Island Sea Lab, 101 Bienville Blvd., Dauphin Island, Alabama 36528, USA \\ ${ }^{2}$ Department of Marine Sciences, University of South Alabama, Mobile, Alabama 36688, USA \\ ${ }^{3}$ Present address: Department of Biology, Sacred Heart University, 5151 Park Avenue, Fairfield, Connecticut 06825, USA
}

\begin{abstract}
While chemical defenses can determine plant persistence in terrestrial ecosystems and some marine macroalgae, their role in determining seagrass persistence in areas of intense grazing is unknown. As a first step toward determining if concentrations of feeding deterrents in seagrasses increase following herbivore attacks, we conducted 4 experiments using a common macrograzer (sea urchin Lytechinus variegatus) and 2 phylogenetically divergent seagrass species (Thalassia testudinum and Halodule wrightii). Macrograzer impacts on production of phenolic acids and condensed tannins varied somewhat idiosyncratically with season, urchin density, and distance from urchin damage. In general, phenolic concentrations were higher in both turtlegrass and shoalgrass in summer than in fall. Grazing led to increased condensed tannin concentrations in T. testudinum but had few effects on turtlegrass phenolic acid concentrations. Turtlegrass $p$-hydroxybenzoic acid concentrations increased locally in the grazed area and in areas $>2 \mathrm{~cm}$ above grazing. Similarly, condensed tannins in grazed $H$. wrightii leaves increased with urchin density in summer but decreased in fall while having few predictable effects on phenolic acid concentrations. Shoalgrass gallic acid concentrations increased in the lowest portions of grazed leaves. In choice feeding experiments in which urchins were offered agar food made with highand low-phenolic seagrass tissue, high phenolic concentrations did not reduce urchin feeding, suggesting that the increases in phenolic concentrations we saw in turtlegrass and shoalgrass did not protect these plants against future sea urchin herbivory but rather some other factor, such as mesograzer feeding or pathogenic infection.
\end{abstract}

KEY WORDS: Chemical deterrent · Condensed tannins · Grazing · Halodule wrightii · Herbivory · Induced defense $\cdot$ Lytechinus variegatus $\cdot$ Thalassia testudinum

\section{INTRODUCTION}

Seagrasses are, inarguably, important ecosystems worldwide. While it was once assumed that seagrass leaves were of little nutritional value and that most of their production was transmitted across adjacent trophic levels via the detrital pathway rather than through the grazing pathway (Mateo et al. 2006), new evidence suggests that this once firmly held paradigm is overly simple (Heck \& Valentine 2006). Some estimates suggest that half or more of the net aboveground primary production of these plants is consumed by herbivores in many locations (Valentine \& Duffy 2006). As such, the new question to be asked is: 'How do such luxurious meadows persist when grazers are consuming significant quantities of the production of these plants?' (Heck \& Valentine 2006).

While many hypotheses have been advanced to explain this apparent contradiction, few have provided any insights into why grazing impacts vary so greatly among regions (Valentine et al. 1997, Valen- 
tine \& Heck 1999). Variation in the presence of chemical defenses is one possible explanation (Heck \& Valentine 2006). Because production of chemical deterrents is energetically costly for plants (Strauss et al. 2002, Cipollini et al. 2003), chronic (constitutive) production of such compounds, at the expense of allocating energy to growth or reproduction, does not make evolutionary sense in environments where grazing is spatially or temporally variable (Valentine et al. 1997 and references therein). Instead, plants are hypothesized to use more cost-effective approaches (e.g. inductively producing chemical deterrents) to reduce the foraging efficiency of their consumers (Karban \& Meyers 1989).

While there are many types of chemical deterrents in plants, phenolic compounds are among the most common. These compounds include low molecular weight phenolic acids and complex polymers, such as condensed tannins and lignins (Constabel 1999). Despite evidence of their widespread occurrence in seagrasses (Zapata \& McMillan 1979, Agostini et al. 1998), the role that phenolic compounds play in seagrass systems has rarely been evaluated. Phenolicrich extracts from eelgrass leaves have antimicrobial properties (Harrison \& Chan 1980, Harrison 1982, Vergeer \& Develi 1997), but the prevalence of phenolics in multiple seagrasses across a broad geographic range suggests that they may also protect seagrasses from some consumers. If true, the presence of phenolic compounds may help explain the persistence of seagrasses in areas where herbivores are abundant (Valentine \& Heck 1999, Little 2000, Heck \& Valentine 2006).

A few studies have shown that grazed seagrasses increase their production of these putative chemical deterrents (Aragones et al. 2006, Moran \& Bjorndal 2007, Arnold et al. 2008). Induction strategies can vary among seagrass species, as Halodule univervis increased concentrations of lignin (a complex polyphenolic) following simulated dugong and turtle grazing, but $H$. ovalis and Zostera capricorni did not (Aragones et al. 2006). Similarly, simulated grazing by turtles and fish led to increased condensed tannin concentrations in Thalassia testudinum leaves (Moran \& Bjorndal 2007, Arnold et al. 2008), while grazing by sea urchins Lytechinus variegatus was linked to increased condensed tannin concentrations in the rhizomes (Arnold et al. 2008). Only a few of these studies have tested the ability of phenolics to deter grazing by seagrass herbivores.

When studies have been conducted, compounds produced by seagrasses altered the feeding preferences of some consumers but not others. Phenolic acids extracted from eelgrass leaves can deter grazing by mesograzers (amphipods; Harrison 1982). Similarly, Verges et al. (2007a) found that macrograzers (urchins) preferred agar food made with Posidonia oceanica leaves containing low levels of phenolics over agar food made with tissues containing higher phenolic concentrations. P. oceanica extracts can also serve as broad spectrum deterrents that reduce grazing by sea urchins and fishes but not a common gastropod mesograzer (Cerithium vulgatum; Verges et al. 2007b).

Isolating the role of phenolics in deterring grazers is complicated by the observations that deterrent concentrations often co-vary with plant nutrient concentrations (Bryant et al. 1983, Buchsbaum et al. 1990, Ravn et al. 1994, Goecker et al. 2005) and that some seagrass grazers preferentially consume nitrogen-rich tissues (Bjorndal 1985, McGlathery 1995, Goecker et al. 2005). Changes in plant nutrient balance, such as those that occur when herbivores preferentially remove nitrogen-rich tissues, are hypothesized to alter phenolic concentrations simply by changing the balance of carbon and nitrogen within plants (i.e. carbon-nutrient balance hypothesis; Bryant et al. 1983, Cronin 2001). If true, this would make separating increases in phenolic concentrations due to herbivory from those due to changes in carbon-nutrient balance all but impossible.

While the carbon-nutrient balance hypothesis (CNB) has been successful in predicting chemical deterrent concentrations in some, mainly terrestrial, plants, this hypothesis is known to be flawed (Hamilton et al. 2001). In fact, although some studies showed relationships between seagrass phenolic and nitrogen concentrations that were consistent with CNB (Buchsbaum et al. 1990, Goecker et al. 2005), others have shown that these same seagrasses do not always conform to CNB (Ravn et al. 1994, L. Steele unpubl. data). Additionally, young seagrass leaves, which occur on the inner portions of seagrass shoots where they are not readily available to most herbivores, often contain higher concentrations of both nitrogen and phenolics than older leaves, again inconsistent with CNB (Ravn et al. 1994, Agostini et al. 1998, L. Steele unpubl. data). Thus, it seems unlikely that simple changes in nutrient balance caused by tissue loss will affect seagrass phenolic concentrations, especially in young leaves.

Given what we know and the fact that grazers are heterogeneously distributed within most marine ecosystems, it is surprising that only a few studies have assessed the ability of seagrasses to inductively produce chemical feeding deterrents (Aragones et al. 
2006, Moran \& Bjorndal 2007, Arnold et al. 2008). Here, we present the results of a study that sought to determine if grazing by the sea urchin Lytechinus variegatus, the numerically most abundant seagrass herbivore in our study area, affects the production of phenolic acids and condensed tannins in turtlegrass Thalassia testudinum and shoalgrass Halodule wrightii leaves in the northern Gulf of Mexico. We then examined the palatability to this urchin of seagrass tissue containing high vs. low phenolic acid concentrations.

\section{MATERIALS AND METHODS}

\section{Field experiments}

To test the hypothesis that macrograzer feeding affects phenolic concentrations in turtlegrass and shoalgrass leaves, 4 separate experiments were conducted in St. Joseph's Bay, FL (USA), an oligotrophic, high salinity bay in the northern Gulf of Mexico, where the macrograzer Lytechinus variegatus is common (Valentine \& Heck 1991, Heck et al. 2000). Although multiple factors may affect phenolic production, the widespread herbivory observed at our study site suggests that grazing may be an important factor driving seagrass phenolic production in this area.

The area in which the experiments were conducted is characterized by Halodule wrightii-dominated meadows near shore, transitioning to a mixed Thalassia testudinum and $H$. wrightii meadow, then a $T$. testudinum-dominated meadow farther from shore. Both the turtlegrass and shoalgrass beds in which our experiments were conducted are found in very shallow water ( 0.5 to $1.5 \mathrm{~m}$, depending on the tide), with high light levels (1200 to $1800 \mu \mathrm{mol}$ photons $\mathrm{m}^{-2} \mathrm{~s}^{-1}$ in the turtlegrass bed, 1800 to $1975 \mu \mathrm{mol}$ photons $\mathrm{m}^{-2}$ $\mathrm{s}^{-1}$ in the shoalgrass bed at the beginning of the summer experiment). Because seagrass production (Valentine \& Heck 1993) and production of phenolics can vary with season (Buchsbaum et al. 1990, Ravn et al. 1994), experiments were conducted during summer and fall.

Grazer treatment levels were established by documenting sea urchin densities at the study site. We counted the number of urchins enclosed within 10 haphazardly placed $0.25 \mathrm{~m}^{2}$ quadrats in a Thalassia testudinum-dominated meadow. Urchin densities ranged from 16 to 48 urchins $\mathrm{m}^{-2}$ (average $=36$ urchins $\mathrm{m}^{-2}$ ), similar to those reported from earlier studies conducted in the region (Valentine \& Heck
1991, 1993). Treatment densities of 0,5, or 10 similarsized urchins were randomly assigned to 12 bottomless $0.25 \mathrm{~m}^{2}$ PVC cages, covered with $1.9 \mathrm{~cm}$ mesh ( $\mathrm{n}=4$ per treatment), enclosing each seagrass species for $4 \mathrm{wk}$. Seagrass densities were similar in all treatments at the beginning of each experiment. Urchins were not observed in Halodule wrightiidominated meadows, so the treatment densities for experiments with both seagrasses were based on urchin density measurements taken only from $T$. testudinum meadows. The rhizomes were severed around the edges of each cage to prevent allochthonous input of nutrients and carbohydrates from outside the experimental arenas (Heck \& Valentine 1995), ensuring replicate independence.

To document treatment effects, seagrass leaves were collected from each cage after 2 wk and again after 4 wk. These sampling times were chosen to detect both induced production of phenolics in grazed leaves within urchin enclosures, which could occur at any time throughout the experiment, and the possible relaxation of phenolic production in grazerfree control plants released from herbivory, which could take several days to several weeks (Van Alstyne 1988, Yates \& Peckol 1993, Peckol et al. 1996, Hemmi et al. 2004). Fifteen haphazardly selected turtlegrass shoots or 50 haphazardly selected shoalgrass shoots were collected from each cage, depending on the experiment. First and second rank leaves (youngest and next youngest leaves) were pooled by rank (sensu Steele et al. 2005) to ensure that there was sufficient tissue for analysis. These ranked leaves were chosen for analysis because they are the youngest and, therefore, presumed to be photosynthetically most valuable to the plant (Durako \& Kunzelman 2002). As such, if seagrasses inductively produce chemical deterrents following grazing, it is most likely that elevated deterrent production would be detected in these leaves.

We also considered that seagrass responses to tissue damage might be limited to damaged leaves or sections of damaged leaves. To test this second hypothesis, grazed turtlegrass leaves were subdivided according to distance from damage then analyzed separately according to the following categories: the grazed leaf tissue, leaf tissue $2 \mathrm{~cm}$ above the grazed tissue, $2 \mathrm{~cm}$ below grazer damage, $>2 \mathrm{~cm}$ above grazer damage, and $>2 \mathrm{~cm}$ below grazer damage. These categories were chosen because previous studies showed that seagrass physiological responses vary among similar locations (Ralph \& Short 2002, Steele et al. 2005). A 3 to $4 \mathrm{~cm}$ section was taken from the center to upper portion of ungrazed control 
leaves. If chemical deterrent production by seagrasses is systemic, grazing on older leaves would trigger increased production of chemical deterrents in ungrazed younger leaves, so ungrazed leaves from cages with no urchins and ungrazed leaves from shoots in which at least 1 leaf was grazed were also compared separately.

Enclosed sea urchins removed distal leaf tissue in shoalgrass, leaving only a few centimeters of basal tissue attached to the shoot. As a result, there were only 4 available tissue categories for shoalgrass comparisons: $2 \mathrm{~cm}$ below grazer damage, $>2 \mathrm{~cm}$ below grazer damage, ungrazed leaves from control cages, and ungrazed leaves taken from grazed shoots.

In all cases, leaves were frozen on dry ice immediately after harvest and held at $-80^{\circ} \mathrm{C}$ prior to freeze drying to prevent oxidation of phenolics in the leaves. They were then ground in liquid nitrogen and were returned to the $-80^{\circ} \mathrm{C}$ freezer until chemical analysis.

Phenolic acid and condensed tannin concentrations in turtlegrass leaves were high at the study site (L. Steele unpubl. data). To determine if the widespread high concentrations of phenolic acids and condensed tannins in Thalassia testudinum leaves was due to chronic grazing, the condensed tannin and total phenolic acid content of turtlegrass leaves collected outside enclosure cages (i.e. continually exposed to macrograzers) were compared to that of turtlegrass leaves from cages with no urchins 2 and $4 \mathrm{wk}$ into the summer experiment. Because monoculture beds of Halodule wrightii occurred in shallower areas where sea urchins were less abundant, the phenolic content of $H$. wrightii leaves collected from outside the enclosure cages was not compared to leaves collected from inside cages with no urchins.

Since herbivory can affect seagrass growth and biomass, potentially diluting or increasing phenolic concentrations, we measured turtlegrass and shoalgrass growth during the summer experiments and aboveground biomass inside experimental cages at the end of the summer experiments (Valentine \& Heck 2001). Growth and biomass were not measured during the fall experiments since doing so would require removing a large proportion of the remaining leaves, a detriment to the overall health of the meadow.

\section{Chemical analyses}

High performance liquid chromatography (HPLC) was used to quantify concentrations of each phenolic acid detected in harvested turtlegrass and shoalgrass leaves as well as total phenolic acid concentrations, following Ravn et al. (1994) and Steele et al. (2005). A colorimetric assay (cf. Arnold \& Schultz 2002) was used to quantify treatment effects on condensed tannin concentrations in samples. Because a commercially available quebracho tannin standard was used, rather than a standard made from seagrass tannins themselves, treatment effects on condensed tannins should not be interpreted as differences in absolute concentrations. These values do, however, provide the basis for the assessment of seagrass herbivore effects on condensed tannin production in these experiments.

\section{Feeding preference experiments}

Laboratory assays were performed to determine if seagrass chemical composition affects sea urchin feeding preferences. There was insufficient tissue collected from the experimental cages for feeding trials, so seagrasses taken from sites known to have very different phenolic concentrations (L. Steele unpubl. data) were offered to sea urchins in 4 choice experiments to assess phenolic impacts on feeding preference over a $24 \mathrm{~h}$ period.

The seagrass samples used in these feeding trials were the same tissues analyzed for phenolic and nitrogen content by L. Steele (unpubl. data), who showed that leaves of both Thalassia testudinum and Halodule wrightii collected from St. Joseph's Bay had higher phenolic concentrations than in those collected from Perdido Bay (FL, USA). Conversely, nitrogen concentration was slightly higher in turtlegrass leaves collected from St. Joseph's Bay than in those collected from Perdido Bay, while there was no difference in nitrogen concentration in the leaves of shoalgrass collected from the 2 sites. In Perdido Bay, there were no differences in either phenolic or nitrogen concentration between species. However, in St. Joseph's Bay, both phenolic and nitrogen concentrations were higher in turtlegrass leaves than in shoalgrass leaves (L. Steele unpubl. data; Table 1).

Based on those results, the paired choices presented in Table 1 were offered to sea urchins Lytechinus variegatus in laboratory experiments. Leaf pairs with comparable nitrogen concentrations (Expt 2, Table 1) were included to control for preferences based on nitrogen rather than phenolics. Leaf pairs with similar phenolic and nitrogen concentrations (Expt 3) were used to consider the possibility that other factors determined urchin feeding preferences, which would be indicated if a preference for one 
Table 1. Table of paired choices used in sea urchin Lytechinus variegatus feeding preference tests. Thalassia testudinum and Halodule wrightii leaves were collected from either Peridido Bay or St. Joseph's Bay, FL (USA)

\begin{tabular}{|lll|}
\hline Expt & \multicolumn{1}{c|}{ Choice 1 } & \multicolumn{1}{c|}{ Choice 2 } \\
\hline 1 & $\begin{array}{l}\text { T. testudinum from Perdido Bay } \\
\text { (low phenolics, low N) }\end{array}$ & $\begin{array}{l}\text { T. testudinum from St. Joseph's } \\
\text { Bay (high phenolics, high N) }\end{array}$ \\
2 & $\begin{array}{l}\text { H. wrightii from Perdido Bay } \\
\text { (low phenolics, similar N) }\end{array}$ & $\begin{array}{l}\text { H. wrightii from St. Joseph's Bay } \\
\text { (high phenolics, similar N) }\end{array}$ \\
3 & $\begin{array}{l}\text { T. testudinum from Perdido Bay } \\
\text { (similar phenolics and N) }\end{array}$ & $\begin{array}{l}\text { H. wrightii from Perdido Bay } \\
\text { (similar phenolics and N) }\end{array}$ \\
T. testudinum from St. Joseph's & $\begin{array}{l}\text { H. wrightii from St. Joseph's Bay } \\
\text { Bay (high phenolics, high N) }\end{array}$ & (low phenolics, low N \\
\hline
\end{tabular}

75.71 experimental tanks equipped with an air stone (1 urchin per tank) and starved for $24 \mathrm{~h}$ to standardize feeding condition. After starvation, randomly selected agar leaf pairs were placed in the tanks in approximately the same position. Three additional leaf pairs were placed in 3 empty tanks as autogenic controls. High- and low-phenolic leaves were distinguished from each other by colored vinyl-covered paperclips secured to the bottom of each leaf. Urchins were moved to the center of each tank when agar leaves were

treatment or the other were detected in Expt 3 (Table 1).

To quantify urchin consumption while controlling for differences in leaf structure among sites and species that affect urchin feeding preferences, ground seagrass tissue from our previous study (L. Steele unpubl. data) was embedded in an agar matrix (cf. Hay 1984, Goecker et al. 2005). A mixture of $20 \mathrm{ml}$ distilled water and $0.3 \mathrm{~g}$ agar was heated and allowed to cool for $\sim 5 \mathrm{~min}$ before adding $0.4 \mathrm{~g}$ (shoalgrass) or $0.6 \mathrm{~g}$ (turtlegrass) of ground seagrass tissue (amount of seagrass tissue was determined based on mean dry mass of a seagrass leaf of equivalent length and width). This mixture was then poured over precut window screen (20 strips cut to $5 \mathrm{~mm} \times 17 \mathrm{~cm}$ ). A sheet of acrylic was placed on top of the strips until the agar solidified to ensure a uniform 'leaf' thickness. The amount of agar mixture consumed by the urchins was quantified by counting the empty squares present at the end of each trial. Autogenic controls (leaf pairs without urchins) were included in each experiment to account for the effects of seawater on the agar. No agar loss was observed during any experiment.

Chemical extraction and analysis were performed on agar leaves that had been soaked in seawater for $24 \mathrm{~h}$ using the methods described above to document that treatment phenolic concentrations still differed from each other following embedding in the agar and soaking in seawater. Phenolic acid concentrations in agar were $~ 50$ to $60 \%$ of the concentrations documented in a previous study (L. Steele unpubl. data).

Sea urchins Lytechinus variegatus were collected from St. Joseph's Bay for use in choice feeding experiments and held in two $0.61 \times 0.61 \times 1.83 \mathrm{~m}$ laboratory tanks with recirculating seawater. Individuals were not reused in replicate trials. Prior to the initiation of each trial, 15 similar-sized urchins were placed in added to ensure each urchin started out the same distance from each leaf. After $24 \mathrm{~h}$, agar leaves were removed, and the number of empty squares on each replicate was recorded. Trials with no grazing after $24 \mathrm{~h}$ were excluded from subsequent statistical analyses.

\section{Statistical analysis}

To test the hypotheses that urchin grazing affects phenolic concentrations in seagrass leaves and that changes in chemical deterrents are localized near urchin damage, condensed tannin and total phenolic acid concentrations were compared among treatments using multi-factor analyses of variance (ANOVA) with season, sampling time, urchin density, leaf rank, and distance from urchin damage as factors, including interactions. Season, sampling time, and leaf rank were included in the ANOVA because each of these factors is known to affect seagrass phenolic concentrations (Ravn et al. 1994, Agostini et al. 1998). Separate multi-factor ANOVA were conducted for condensed tannins and total phenolic acids in each species. When significant treatment effects were detected $(p<0.05)$, post-hoc Tukey multiple comparisons were used to identify significant treatment effects. Condensed tannin data were arcsine transformed (Zar 1999), and total phenolic acid data were square root transformed to normalize the data.

Although individual phenolic acid data might best be analyzed using multivariate techniques, such as multivariate ANOVA (MANOVA) with the same factors described above or principle components analysis (PCA), transformation failed to normalize the distributions of the concentrations of 5 of the 6 phenolic acids ( $p$-hydroxybenzoic acid concentrations were 
normally distributed) quantified in turtlegrass. Similarly, $p$-hydroxybenzoic acid, ferulic acid, and pcoumaric acid from Halodule wrightii were square root transformed to normalize the data, but distributions of the other 3 phenolic acids could not be normalized via transformation. Since MANOVA and PCA are inappropriate for use with data with nonnormal distributions, and permutational ANOVA, a non-parametric version of MANOVA, can only be performed on balanced designs, multivariate analysis of individual phenolic acids was not possible (Quinn \& Keough 2002). Because ANOVA is robust to data with non-normal distributions (Quinn \& Keough 2002), multi-factor ANOVA with the same factors described above were used to determine the effects of season, sampling time, urchin density, leaf rank, and distance from urchin damage on concentrations of individual phenolic acids from both seagrasses. When data were not normal, ANOVA results were confirmed with a non-parametric KruskalWallis test.

Two-way ANOVA with factors of sampling time (initial/uncaged, $2 \mathrm{wk}, 4 \mathrm{wk}$ ) and leaf rank were conducted to compare condensed tannin and total phenolic acid concentrations of uncaged seagrass leaves continually exposed to grazing to those of caged control leaves released from herbivory.

Paired $t$-tests were used to compare leaf consumption in the preference experiments (Peterson \& Renaud 1989). Data were log transformed $(y+1)$ to satisfy the assumptions of the test. Four separate $t$-tests were performed, one for each of the feeding experiments (Table 1). Since there were no changes in the autogenic controls, these data were not included in subsequent analyses.

One-way ANOVA were used to determine if turtlegrass and shoalgrass growth and biomass differed among treatments in the summer experiments.

\section{RESULTS}

\section{Thalassia testudinum field experiments}

Concentrations of condensed tannins and total phenolic acids in turtlegrass leaves varied idiosyncratically with both urchin density and season but were unaffected by sampling time, leaf rank, or distance from urchin damage. Condensed tannin concentrations were significantly higher in leaves taken from cages enclosing 10 urchins than in those taken from cages containing 0 or 5 urchins $\left(F_{2,206}=4.89, \mathrm{p}=\right.$ 0.008 ; Fig. 1), suggesting that production of these

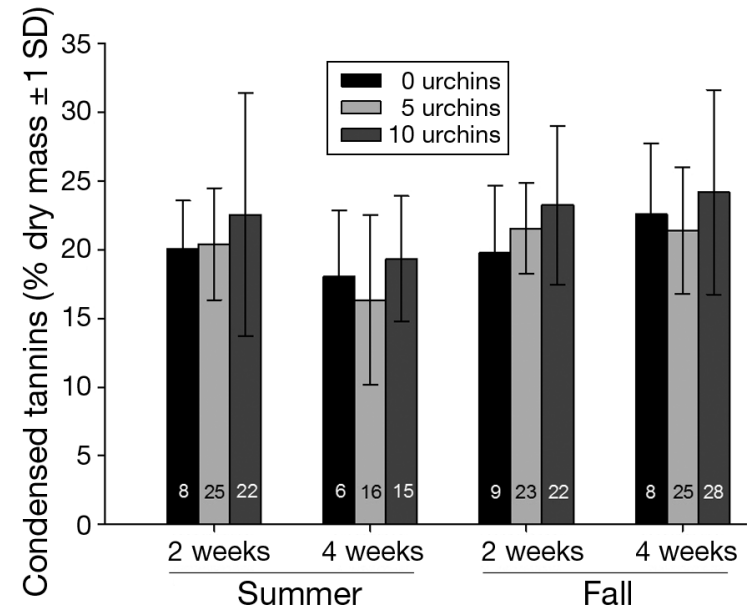

Fig. 1. Percent condensed tannins $(\bar{x} \pm 1$ SD) of Thalassia testudinum leaves collected from cages containing 0,5 , or 10 sea urchins Lytechinus variegatus for 2 and 4 wk during summer and fall. Sample size for each treatment and sampling time is indicated by the number on each bar

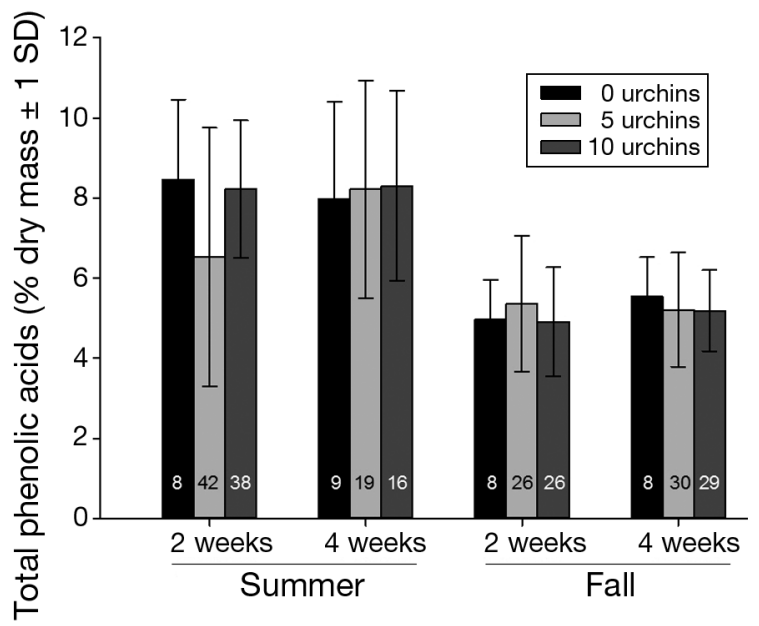

Fig. 2. Percent total phenolic acids $(\bar{x} \pm 1 \mathrm{SD})$ of Thalassia testudinum leaves collected from cages containing 0,5 , or 10 sea urchins Lytechinus variegatus for 2 and 4 wk during summer and fall. Sample size for each treatment and

sampling time is indicated by the number on each bar

compounds may be induced by grazing in turtlegrass. Oddly, condensed tannin concentrations were also higher in turtlegrass leaves collected during fall than in those collected during summer $\left(F_{1,206}=7.91\right.$, $p=0.005$; Fig. 1). This result is surprising because seagrass production declines in fall when light availability is reduced, leading to fewer resources for tannin production. There were no significant interactions among factors in the ANOVA conducted on turtlegrass condensed tannins.

Patterns of total phenolic acid concentrations in turtlegrass leaves differed from those of condensed 


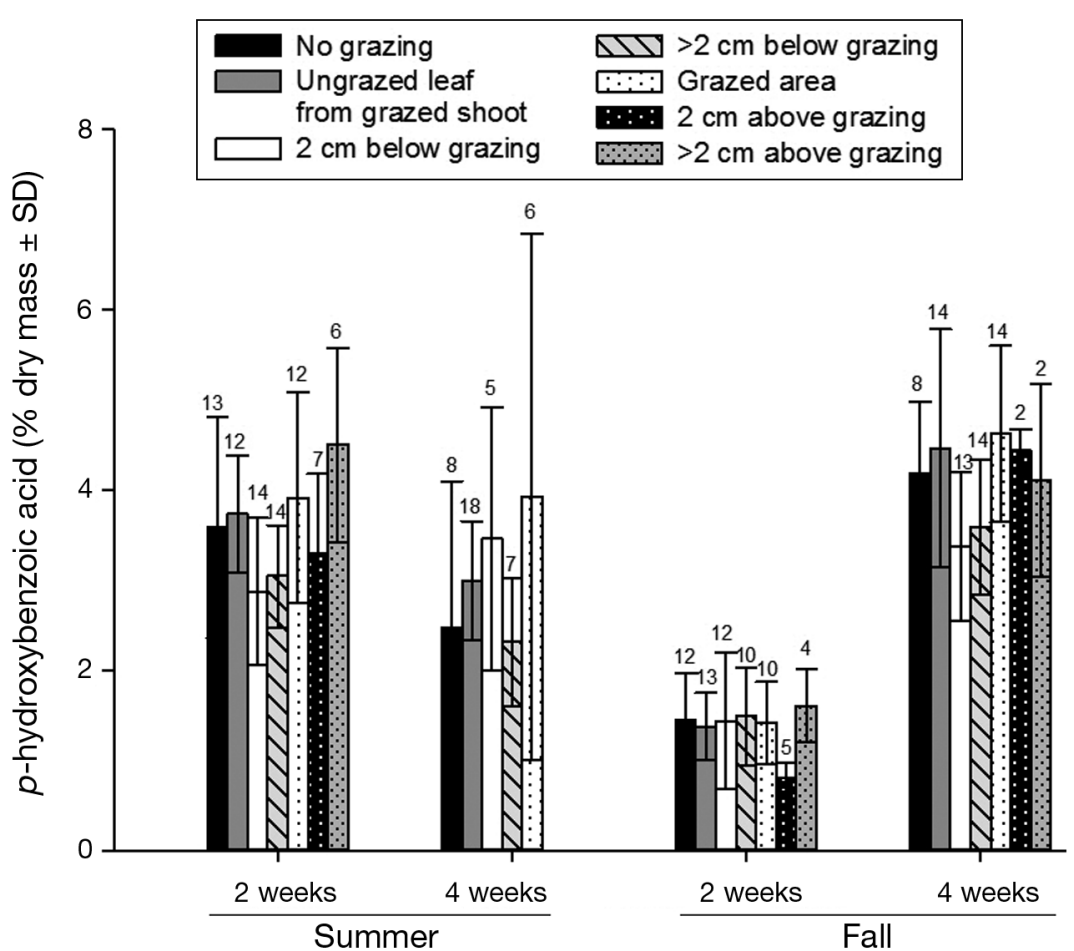

Fig. 3. Percent $p$-hydroxybenzoic acid $(\bar{x} \pm 1 \mathrm{SD})$ in Thalassia testudinum leaf tissue at different distances from sea urchin Lytechinus variegatus grazing damage for 2 and $4 \mathrm{wk}$ during summer and fall. Sample size for each tissue and sampling time is indicated by the number over each error bar in the grazed area and $>2 \mathrm{~cm}$ above the grazed area than in tissues $2 \mathrm{~cm}$ or $>2 \mathrm{~cm}$ below grazer damage (Fig. 3).

Condensed tannin concentrations did not vary among turtlegrass leaves collected from outside experimental cages, within caged controls after $2 \mathrm{wk}$ and within caged controls after 4 wk $\left(F_{2,21}=0.73, \mathrm{p}=0.495\right)$, or between leaf ranks $\left(F_{1,21}=0.26, \mathrm{p}=\right.$ $0.616)$, suggesting that factors other than urchin herbivory drove turtlegrass condensed tannin production. However, total phenolic acid concentrations were lower in turtlegrass leaves taken from control cages after 2 and 4 wk than in uncaged leaves $\left(F_{2,21}=7.26, \mathrm{p}=0.005\right.$; Fig. 4$)$ as well as being lower in second rank leaves than in first rank leaves $\left(F_{1,21}=4.85\right.$, $\mathrm{p}=0.041$; Fig. 3).

Mean turtlegrass growth during summer ranged among treatments from 3.09 to $4.35 \mathrm{~g}$ dry mass $\mathrm{m}^{-2} \mathrm{~d}^{-1}$, and mean aboveground biomass ranged from 227 to $293 \mathrm{~g}$ dry mass $\mathrm{m}^{-2}$. ANOVA detected no significant tannins. Although ANOVA detected a significant effect of urchin density on total phenolic acid concentration in turtlegrass leaves $\left(F_{2,258}=3.30, \mathrm{p}=0.038\right)$, pairwise comparisons showed no significant differences among urchin densities (Fig. 2), perhaps due to a significant interaction between urchin density and season $\left(F_{2,258}=3.66, \mathrm{p}=0.027\right)$. This interaction, the only significant interaction term in the ANOVA, indicates that total phenolic acid concentrations responded differently to urchin density between seasons, but no clear pattern emerged (Fig. 2). Unlike condensed tannins, total phenolic acid concentrations were significantly higher in turtlegrass leaves collected during summer than in those collected in the fall $\left(F_{1,258}=67.33, \mathrm{p}<0.001\right.$; Fig. 2), consistent with our expectations.

Individual phenolic acid concentrations varied unpredictably with season and sampling time (2 or $4 \mathrm{wk}$ ) and did not change with urchin density. Most phenolic acids were likewise unaffected by leaf rank, with the exception of ferulic acid, which was present in higher concentrations in first rank leaves than in second rank leaves $\left(F_{1,261}=135.59, \mathrm{p}<0.001\right)$. Only $p$ hydroxybenzoic acid concentrations varied significantly with distance from urchin damage $\left(F_{6,254}=\right.$ $4.74, \mathrm{p}<0.001)$, with higher concentrations occurring differences in leaf growth or aboveground biomass among grazing treatments, suggesting that tissue losses due to herbivory were unlikely to have changed plant nutrient balance, which probably had minimal, if any, effects on phenolic concentrations.

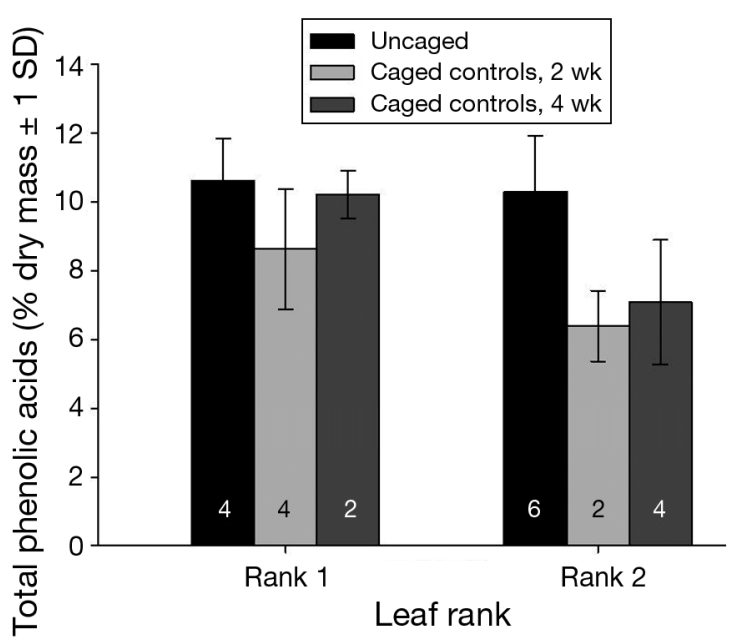

Fig. 4. Percent total phenolic acids $(\bar{x} \pm 1$ SD) in Rank 1 (youngest) and Rank 2 (next youngest) Thalassia testudinum leaves collected from uncaged plots and caged controls for 2 and 4 wk during summer and fall. Sample size for each treatment and leaf rank is indicated by the number on each bar 

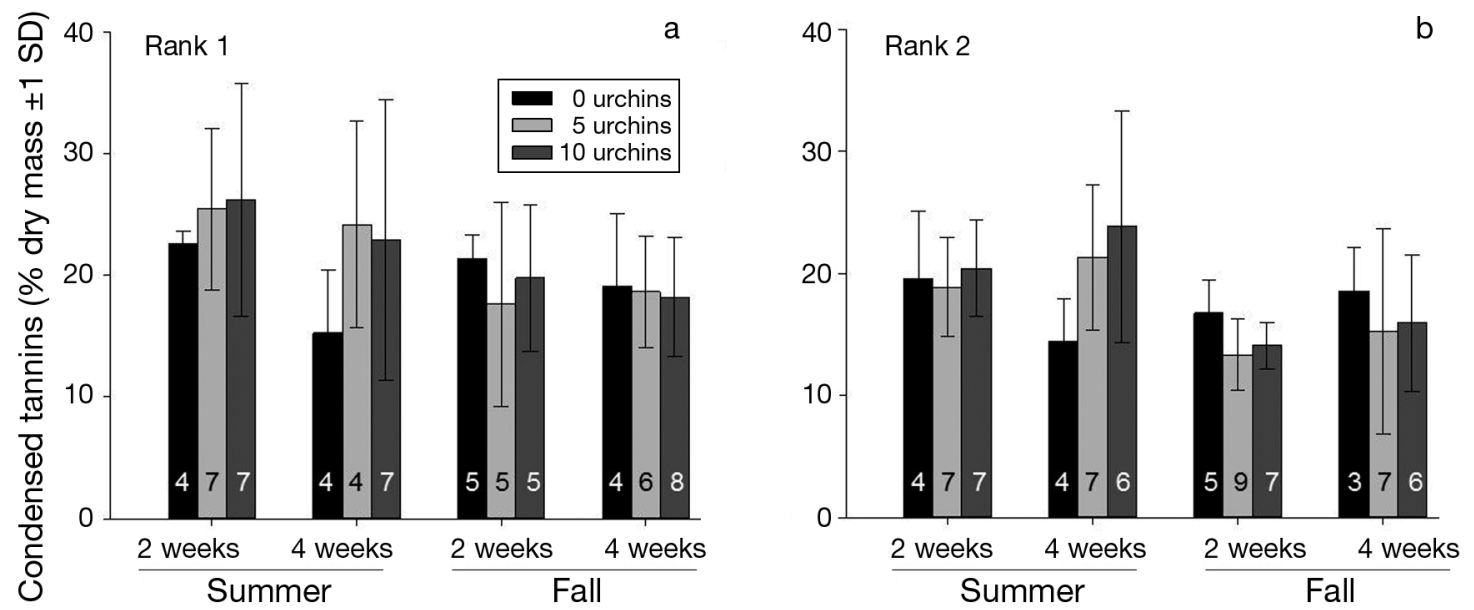

Fig. 5. Percent condensed tannins ( $\bar{x} \pm 1 \mathrm{SD}$ ) in (a) Rank 1 (youngest) and (b) Rank 2 (next youngest) Halodule wrightii leaves collected from cages containing 0, 5, or 10 sea urchins Lytechinus variegatus for 2 and 4 wk during summer and fall. Sample size for each treatment and sampling time is indicated by the number on each bar

\section{Halodule wrightii field experiments}

Shoalgrass condensed tannin concentrations were affected by multiple factors in the ANOVA, but they did not vary with sampling time or distance from urchin damage. Condensed tannin concentrations were higher in shoalgrass leaves collected during summer than in leaves collected during fall $\left(F_{1,137}=\right.$ 15.91, p $<0.001$; Fig. 5). They were likewise higher in first rank leaves than in second rank leaves $\left(F_{1,137}=\right.$ 13.37, p < 0.001; Fig. 5). Although the effect of urchin density on condensed tannin concentration was not significant, there was a significant interaction between urchin density and season $\left(F_{2,137}=4.94, \mathrm{p}=\right.$ 0.009), meaning that condensed tannin concentrations responded differently to urchin density depending on the season. In the summer, condensed tannin concentrations increased with increasing urchin density, while concentrations decreased with increasing urchin density in the fall (Fig. 5).

Unlike condensed tannins, shoalgrass total phenolic acid concentrations were unaffected by most of the ANOVA factors, except for season. Similar to condensed tannins, total phenolic acid concentrations were higher in shoalgrass leaves collected during summer than in those collected during fall $\left(F_{1,174}=9.29, \mathrm{p}<0.001\right)$, consistent with predictions based on light availability and established seagrass productivity patterns.

Concentrations of individual phenolic acids in shoalgrass varied unpredictably, making it difficult to draw conclusions about the effects of most treatment factors. Syringic acid and p-hydroxybenzoic acid concentrations were higher in summer than in fall, consistent with the total phenolic acid results, suggesting that concentrations of these 2 acids drove the seasonal variation in total phenolic acid concentrations since concentrations of the other 4 phenolic acids did not vary seasonally (syringic acid KruskalWallis: $H=27.26, \mathrm{p}<0.001$; $p$-hydroxybenzoic acid ANOVA: $\left.F_{1,172}=52.61, \mathrm{p}<0.001\right)$. None of the shoalgrass' 6 individual phenolic acids varied with urchin density, but syringic acid and gallic acid were affected by distance from urchin damage (syringic acid Kruskal-Wallis: $H=12.40, \mathrm{p}=0.006$; gallic acid Kruskal-Wallis: $H=8.27, \mathrm{p}=0.041$ ). Pairwise comparisons of syringic acid concentrations among tissue locations detected no significant differences. However, pairwise comparisons showed that tissues $>2 \mathrm{~cm}$ below urchin damage contained more gallic acid than ungrazed control leaves and ungrazed leaves from grazed shoots (Fig. 6).

Mean shoalgrass growth ranged from 51.5 to $63.99 \mathrm{~g}$ dry mass $\mathrm{m}^{-2} \mathrm{~d}^{-1}$ among grazing treatments, and mean aboveground biomass ranged from 139 to $191 \mathrm{~g}$ dry mass $\mathrm{m}^{-2}$. Growth rates reported here for Halodule wrightii may be erroneously high due to difficulties in puncturing all leaves on a shoot under field conditions. ANOVA detected no significant differences in either growth or aboveground biomass among the grazing treatments.

\section{Laboratory feeding experiments}

Seagrass chemical composition had no effect on urchin herbivory in the feeding trials. In the first experiment, urchins consumed agar leaves made 


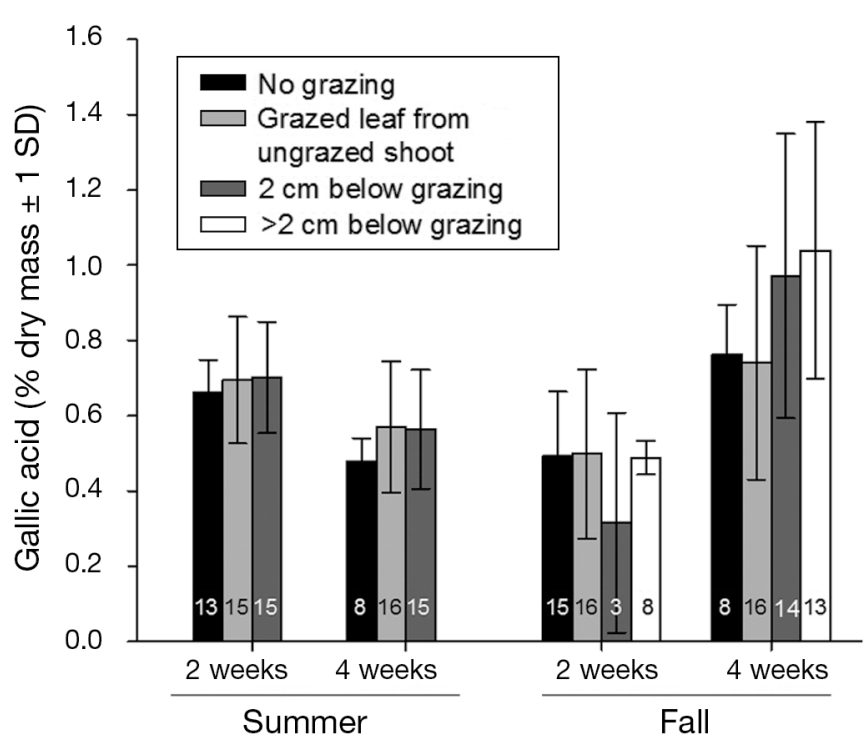

Fig. 6. Percent gallic acid $(\bar{x} \pm 1 \mathrm{SD})$ in Halodule wrightii leaves exposed to grazing by the sea urchin Lytechinus variegatus for 2 and 4 wk during summer and fall. Sample size for each treatment and sampling time is indicated by the number on each bar

with Thalassia testudinum from St. Joseph's Bay and Perdido Bay equally ( $t=0.46, \mathrm{p}=0.648$; Fig. 7). Likewise, they failed to show a preference for lower phenolic content Halodule wrightii collected from Perdido Bay over high phenolic content leaves from St. Joseph's Bay ( $t=0.69, \mathrm{p}=0.503$; Fig. 7). As would be expected if either phenolic or nitrogen concentrations determined urchin feeding preferences, urchins consumed similar amounts of agar made with T. testudinum and $H$. wrightii from Perdido Bay $(t=1.16$, $\mathrm{p}=0.274$; Fig. 7), which did not differ in either phenolic or nitrogen content. Finally, urchins showed no preference for agar made with $T$. testudinum over $H$. wrightii leaves collected from St. Joseph's Bay $(t=$ 0.49, p = 0.642; Fig. 7), even though T. testudinum had both more nitrogen and higher levels of phenolics than $H$. wrightii at that site.

\section{DISCUSSION}

In the present study, we sought to test the extent to which the chemical composition of the leaves of 2 phylogenetically distant seagrasses could explain their persistence in areas known to support an abundance of macrograzers (cf. Heck \& Valentine 2006). Because of the known metabolic costs of producing such compounds and the patchy distributions of marine macrograzers, we predicted that if seagrasses used chemical deterrents to limit herbivore feeding, they would do so inductively. We first conducted assessments of induced responses in the seagrasses followed by choice feeding experiments to evaluate the effects of phenolics on herbivore feeding preferences.

We predicted that phenolic concentrations would increase with increasing urchin densities. There was some evidence that condensed tannin production by both turtlegrass and shoalgrass was induced in the grazer enclosures, though this only occurred in summer in the case of shoalgrass (Figs. $1 \& 5$ ). We found little evidence that plant investment in potentially defensive compounds varied with leaf age, perhaps because our study focused only the youngest, most phenolic-rich seagrass leaves (Ravn et al. 1994, Agostini et al. 1998). We did, however, find evidence that grazer damage could induce production of some compounds in localized areas in both turtlegrass and shoalgrass (Figs. 3 \& 6).
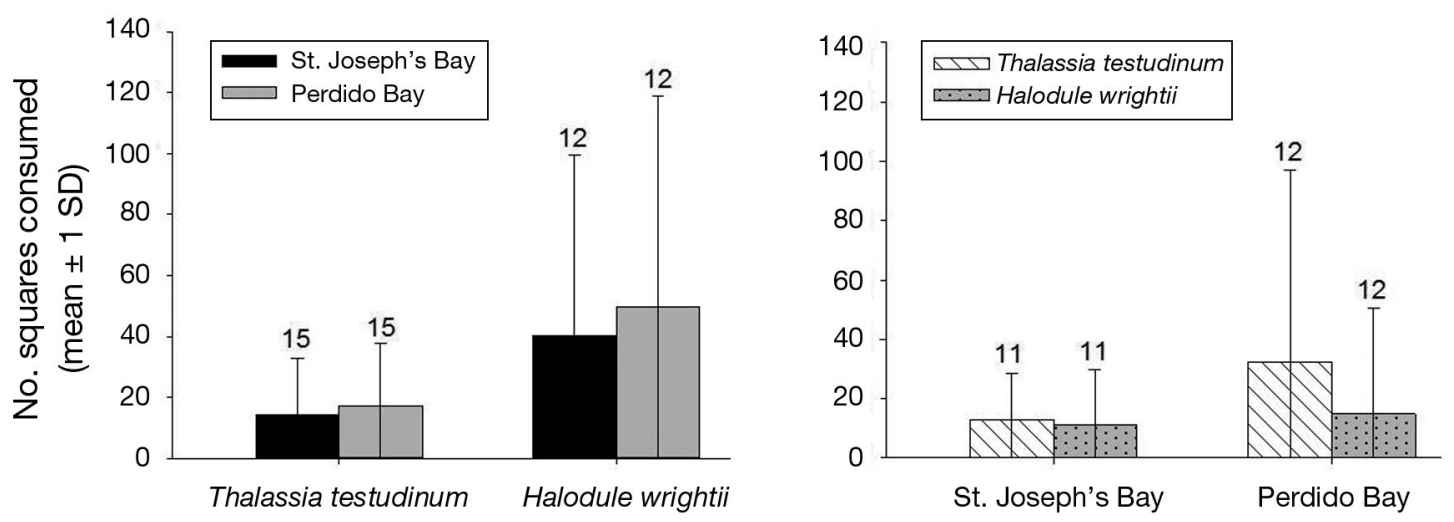

Fig. 7. Number of squares ( $\bar{x} \pm 1 \mathrm{SD}$ ) of agar containing seagrass tissue from either Thalassia testudinum or Halodule wrightii collected from either St. Joseph's Bay or Perdido Bay, FL (USA) consumed by the sea urchin Lytechinus variegatus in choice feeding experiments. Sample size for each treatment is indicated by the number over each error bar 
Notably, urchin density had the opposite of the predicted effect on condensed tannin production by shoalgrass in the fall. Although the pattern was unclear, the significant effect of urchin density and the interaction between urchin density and season suggest a similar pattern of total phenolic acid production by turtlegrass. These responses imply that there are costs associated with the production of these compounds. While the costs of producing phenolic compounds have not been explicitly tested in seagrasses, producing chemical deterrents of this type is known to be metabolically costly in other species (Strauss et al. 2002, Cipollini et al. 2003). We suggest that the localized responses of $p$-hydroxybenzoic acid in turtlegrass and gallic acid in shoalgrass, coupled with the shutdown of condensed tannin production by shoalgrass with increasing urchin density in the fall, points to a metabolic cost.

While our evidence that sea urchin herbivoryinduced production of phenolics in turtlegrass and shoalgrass was somewhat limited, as concentrations of most of the individual phenolic acids did not change with either urchin density or distance from urchin damage, we still considered the possibility that seagrass chemical composition might be one factor affecting macrograzer feeding preferences by conducting a series of paired choice tests in which we offered urchins agar food made with seagrass tissue containing high or low phenolic concentrations. Because the results of the feeding trials failed to detect evidence of an urchin preference, it appears that this urchin is unaffected by seagrass chemical composition. This contrasts with our expectations based on other urchin feeding preference studies, including some with Lytechinus variegatus, showing that macroalgal and seagrass chemistry, along with structural defenses, can strongly affect urchin feeding preferences (McConnell et al. 1982, Verges et al. 2007b, Souza et al. 2008).

The localized responses by turtlegrass and shoalgrass, along with the results of the feeding trials, also suggest that the increases in phenolic acids in our experiments did not occur to deter sea urchin feeding. Such localized responses are known to be most effective in deterring feeding by small herbivores (Hay 1996, Järemo et al. 1999), so it is possible that this local production of specific phenolic acids occurred to deter subsequent attacks by mesograzers (such as amphipods, gastropods, and isopods) that would remove photosynthetically valuable epidermal tissue. Mesograzers can also affect the production of secondary metabolites (Hay 1996, Pavia \& Toth 2000). If it is mesograzers, rather than macro- grazers like sea urchins, that are deterred by changes in seagrass phenolic production, and if mesograzer damage induces production of phenolics in seagrasses, this could also explain why turtlegrass condensed tannin concentrations remained high in the control cages, where macrograzers were excluded but mesograzers could enter freely (Fig. 4).

Alternatively, the increases in phenolic concentrations that we observed in grazed leaves might function to prevent post-damage infection of the wound sites. There is some evidence that seagrass secondary metabolites can deter a variety of microorganisms, including bacteria, the wasting disease pathogen Labyrinthula spp., and fungi (Harrison 1982, Vergeer \& Develi 1997, Jensen et al. 1998, Ross et al. 2008). Pathogenic infection can also influence seagrass phenolic concentrations (Vergeer \& Develi 1997, Steele et al. 2005), suggesting that defenses against infection may also be inducible. Given that such a variety of microorganisms can infect seagrass tissues and that grazer damage provides an opening for pathogenic organisms to freely invade seagrass cells, it seems likely that increased concentrations of phenolics in damaged seagrass tissues could function as defenses against these types of infections.

Likewise, at least some phenolic compounds may be targeted at wound healing rather than defense, as suggested by the increase in $p$-hydroxybenzoic acid in the grazed portion of turtlegrass leaves. Many plant extracts containing phenolics are known to hasten wound healing in cultured skin cells and mice (Phan et al. 2001, Regalado et al. 2009). Surprisingly, the role of phenolics in healing plant wounds seems to be rarely studied outside of agriculture, where phenolics have been associated with wound healing in potatoes (Ramamurthy et al. 1992).

The declines in phenolic production that occurred in both seagrasses during fall, and especially the decline in shoalgrass condensed tannin concentrations with increasing urchin density in fall, suggest that grazing may be more detrimental when seagrass photosynthesis and production slow. Under these conditions, it may not be beneficial for seagrasses to expend resources on chemical deterrents. Thus, the plant cuts its losses by surrendering leaves to grazers and growing new leaves in the spring. Alternatively, it is also possible that with cooling water temperatures and thus lowered metabolic activity, along with reduced light availability, these seagrasses produce fewer phenolics in general in the fall, as they go dormant until spring.

Phenolics may also protect plants against ultraviolet radiation, which can affect plant phenolic concen- 
trations (Vergeer et al. 1995, Pavia et al. 1997, Close \& McArthur 2002). The decline in phenolic production in fall, when exposure to high ultraviolet light levels is less likely, suggests that this may be true. However, it seems that if photoprotection was the primary function of phenolic compounds, then phenolic concentrations would be higher in Halodule wrightii, which is usually found in shallower waters with higher light exposure than Thalassia testudinum. We found in a previous study (L. Steele unpubl. data) that $T$. testudinum had higher phenolic acid concentrations than $H$. wrightii, indicating that this is not the case.

Phenolics have many potential roles in seagrasses, and their concentrations can be influenced by many of the stressors described above. Although many factors other than grazing may certainly influence seagrass phenolic concentrations, our results confirm that herbivory cannot be ignored as a determinant of seagrass chemical composition. However, smaller mesograzers may also be important since condensed tannin concentrations remained high in turtlegrass leaves in control cages, where they were released from urchin herbivory.

Acknowledgements. All experiments and seagrass collection were conducted in accordance with Florida Fish and Wildlife Conservation Commission Special Activities License \#05SR-338A, Florida Department of Environmental Protection Permit \#07050311, and a Florida Department of Environmental Protection De Minimus Exemption. C. Steele, M. Cook, G. Goodrich, C. Martin, R. Plutchak, K. Darnell, and J. Blaine provided help in the field, and A. Boettcher and T. Sherman offered helpful advice and use of their labs. T. Arnold and K. Heck provided valuable input toward the design of this study. This work was funded by the Department of Marine Sciences at the University of South Alabama, the Dauphin Island Sea Lab, and the Alabama Center for Estuarine Studies (ACES).

\section{LITERATURE CITED}

Agostini S, Desjobert J, Pergent G (1998) Distribution of phenolic compounds in the seagrass Posidonia oceanica. Phytochemistry 48:611-617

> Aragones LV, Lawler IR, Foley WJ, Marsh H (2006) Dugong grazing and turtle cropping: grazing optimization in tropical seagrass systems? Oecologia 149:635-647

> Arnold TM, Schultz JC (2002) Induced sink strength as a prerequisite for tannin biosynthesis in Populus. Oecologia 130:585-593

Arnold TM, Tanner CE, Rothen M, Bullington J (2008) Wound-induced accumulations of condensed tannins in turtlegrass Thalassia testudinum. Aquat Bot 89:27-33

Bjorndal KA (1985) Nutritional ecology of sea turtles. Copeia 3:736-751

> Bryant JP, Chapin FS III, Klein DR (1983) Carbon/nutrient balance of boreal plants in relation to vertebrate her- bivory. Oikos 40:357-368

Buchsbaum RN, Short FT, Cheney DP (1990) Phenolicnitrogen interactions in eelgrass, Zostera marina L.: possible implications for disease resistance. Aquat Bot 37: 291-297

Cipollini D, Purrington CB, Bergelson J (2003) Costs of induced responses in plants. Basic Appl Ecol 4:79-85

Close DC, McArthur C (2002) Rethinking the role of many plant phenolics - protection from photodamage not herbivores? Oikos 99:166-172

Constabel CP (1999) A survey of herbivore-inducible defensive proteins and phytochemicals. In: Agrawal AA, Tuzun S, Bent E (eds) Induced plant defenses against pathogens and herbivores. APS Press, St. Paul, MN, p 137-166

Cronin G (2001) Resource allocation in seaweeds and marine invertebrates: chemical defense patterns in relation to defense theories. In: McClintock JB, Baker BJ (eds) Marine chemical ecology. CRC Press, Boca Raton, FL, p 325-353

Durako MJ, Kunzelman JI (2002) Photosynthetic characteristics of Thalassia testudinum measured in situ by pulseamplitude modulated (PAM) fluorometry: methodological and scale-based considerations. Aquat Bot 73: 173-185

Goecker ME, Heck KL Jr, Valentine JF (2005) Effects of nitrogen concentrations in turtlegrass Thalassia testudinum on consumption by the bucktooth parrotfish Sparisoma radians. Mar Ecol Prog Ser 286:239-248

> Hamilton JG, Zangerl AR, DeLucia EH, Berenbaum MR (2001) The carbon-nutrient balance hypothesis: its rise and fall. Ecol Lett 4:86-95

- Harrison PG (1982) Control of microbial growth and of amphipod grazing by water-soluble compounds from leaves of Zostera marina. Mar Biol 67:225-230

Harrison PG, Chan AT (1980) Inhibition of the growth of micro-algae and bacteria by extracts of eelgrass (Zostera marina) leaves. Mar Biol 61:21-26

Hay ME (1984) Predictable spatial escapes from herbivory: How do these affect the evolution of herbivore resistance in tropical marine communities? Oecologia 64:396-407

> Hay ME (1996) Marine chemical ecology: What's known and what's next? J Exp Mar Biol Ecol 200:103-134

Heck KL Jr, Valentine JF (1995) Sea urchin herbivory: evidence for long-lasting effects in subtropical seagrass meadows. J Exp Mar Biol Ecol 189:205-217

> Heck KL Jr, Valentine JF (2006) Plant-herbivore interactions in seagrass meadows. J Exp Mar Biol Ecol 330:420-436

Heck KL Jr, Pennock JR, Valentine JF, Coen LD, Sklenar SA (2000) Effects of nutrient enrichment and small predator density on seagrass ecosystems: an experimental assessment. Limnol Oceanogr 45:1041-1057

> Hemmi A, Honkanen T, Jormalainen V (2004) Inducible resistance in Fucus vesiculosus-duration, spreading and variation with nutrient availability. Mar Ecol Prog Ser 273:109-120

Järemo J, Tuomi J, Nilsson P (1999) Adaptive status of localized and systemic defense responses in plants. In: Tollrian R, Harvell CD (eds) The ecology and evolution of inducible defenses. Princeton University Press, Princeton, $\mathrm{p}$ 33-44

Jensen PR, Jenkins KM, Porter D, Fenical W (1998) Evidence that a new antibiotic flavone glycoside chemically defends the sea grass Thalassia testudinum against zoosporic fungi. Appl Environ Microbiol 64:1490-1496 
Karban R, Meyers JH (1989) Induced plant responses to herbivory. Annu Rev Ecol Syst 20:331-348

Little C (2000) The biology of soft shores and estuaries. Oxford University Press, Oxford, p 67-68

Mateo MA, Cebrian J, Dunton K, Mutchler T (2006) Carbon flux in seagrass ecosystems. In: Larkum AWD, Orth RJ, Duarte CM (eds) Seagrasses: biology, ecology, and conservation. Springer, Dordrecht, p 159-192

McConnell OJ, Hughes PA, Targett NM, Daley J (1982) Effects of secondary metabolites from marine algae on feeding by the sea urchin, Lytechinus variegatus. J Chem Ecol 8:1437-1453

- McGlathery KJ (1995) Nutrient and grazing influences on a subtropical seagrass community. Mar Ecol Prog Ser 122: 239-252

Moran KL, Bjorndal KA (2007) Simulated green turtle grazing affects nutrient composition of the seagrass Thalassia testudinum. Mar Biol 150:1083-1092

Pavia H, Toth GB (2000) Inducible chemical resistance to herbivory in the brown seaweed Ascophyllum nodosum. Ecology 81:3212-3225

> Pavia H, Cervin G, Lindgren A, Aberg P (1997) Effects of UV-B radiation and simulated herbivory on phlorotannins in the brown alga Ascophyllum nodosum. Mar Ecol Prog Ser 157:139-146

> Peckol P, Krane JM, Yates JL (1996) Interactive effects of inducible defense and resource availability on phlorotannins in the North Atlantic brown alga Fucus vesiculosus. Mar Ecol Prog Ser 138:209-217

Peterson $\mathrm{CH}$, Renaud PE (1989) Analysis of feeding preference experiments. Oecologia 80:82-86

Phan TT, Wang L, See P, Grayer RJ, Chan SY, Lee ST (2001) Phenolic compounds of Chromolaena odorata protect cultured skin cells from oxidative damage: implication for cutaneous wound healing. Biol Pharm Bull 24: 1373-1379

Quinn GP, Keough MJ (2002) Experimental design and data analysis for biologists. Cambridge University Press, New York, NY

Ralph PJ, Short FT (2002) Impact of the wasting disease pathogen, Labyrinthula zosterae, on the photobiology of eelgrass Zostera marina. Mar Ecol Prog Ser 226:265-271

Ramamurthy MS, Maiti B, Thomas P, Nair PM (1992) Highperformance liquid chromatography determination of phenolic acids in potato tubers (Solanum tuberosum) during wound healing. J Agric Food Chem 40:569-572

Ravn H, Pedersen MF, Borum J, Andary C, Anthoni U, Christophersen C, Nielsen PH (1994) Seasonal variation and distribution of two phenolic compounds, rosmarinic acid and caffeic acid, in leaves and roots-rhizomes of eelgrass (Zostera marina L). Ophelia 40:51-61

Regalado EL, Rodriguez M, Menéndez R, Concepción AA and others (2009) Repair of UVB-damaged skin by the antioxidant sulphated flavone glycoside thalassiolin B isolated from the marine plant Thalassia testudinum Banks ex König. Mar Biotechnol 11:74-80

Ross C, Puglisi MP, Paul VJ (2008) Antifungal defenses of seagrasses from the Indian River Lagoon, Florida. Aquat Bot 88:134-141

Souza CF, de Oliveria AS, Pereira RC (2008) Feeding prefer-

Editorial responsibility: Morten Pedersen,

Roskilde, Denmark ence of the sea urchin Lytechinus variegatus (Lamarck, 1816) on seaweeds. Braz J Oceanogr 56:239-247

Steele L, Caldwell M, Boettcher A, Arnold T (2005) Seagrass-pathogen interactions: 'pseudo-induction' of turtlegrass phenolics near wasting disease lesions. Mar Ecol Prog Ser 303:123-131

> Strauss SY, Rudgers JA, Lau JA, Irwin RE (2002) Direct and ecological costs of resistance to herbivory. Trends Ecol Evol 17:278-285

Valentine JF, Duffy JE (2006) The central role of grazing in seagrass ecology. In: Larkum AWD, Orth RJ, Duarte CM (eds) Seagrasses: biology, ecology, and conservation. Springer, Dordrecht, p 463-501

Valentine JF, Heck KL Jr (1991) The role of sea urchin grazing in regulating subtropical seagrass meadows: evidence from field manipulations in the northern Gulf of Mexico. J Exp Mar Biol Ecol 154:215-230

- Valentine JF, Heck KL Jr (1993) Mussels in seagrass meadows: their influence on macroinvertebrate abundance and secondary production in the northern Gulf of Mexico. Mar Ecol Prog Ser 96:63-74

> Valentine JF, Heck KL Jr (1999) Seagrass herbivory: evidence for the continued grazing of marine grasses. Mar Ecol Prog Ser 176:291-302

> Valentine JF, Heck KL Jr (2001) The role of leaf nitrogen content in determining turtlegrass (Thalassia testudinum) grazing by a generalized herbivore in the northeastern Gulf of Mexico. J Exp Mar Biol Ecol 258: 65-86

> Valentine JF, Heck KL Jr, Busby J, Webb D (1997) Experimental evidence that herbivory can increase shoot density in a subtropical turtlegrass (Thalassia testudinum) meadow. Oecologia 112:193-200

Van Alstyne KL (1988) Herbivore grazing increases polyphenolic defenses in the intertidal brown alga Fucus distichus. Ecology 69:655-663

Vergeer LHT, Develi A (1997) Phenolic acids in healthy and infected leaves of Zostera marina and their growth-limiting properties towards Labyrinthula zosterae. Aquat Bot 58:65-72

Vergeer LHT, Aarts TL, de Groot JD (1995) The 'wasting disease' and the effect of abiotic factors (light, temperature, salinity) and infection with Labyrinthula zosterae on the phenolic content of Zostera marina shoots. Aquat Bot 52: 35-44

Verges A, Becerro MA, Alcoverro T, Romero J (2007a) Variation in multiple traits of vegetative and reproductive tissues influences plant-herbivore interactions. Oecologia 151:675-686

Verges A, Becerro MA, Alcoverro T, Romero J (2007b) Experimental evidence of chemical deterrence against multiple herbivores in the seagrass Posidonia oceanica. Mar Ecol Prog Ser 343:107-114

Yates JL, Peckol P (1993) Effects of nutrient availability and herbivory on polyphenolics in the seaweed Fucus vesiculosus. Ecology 74:1757-1766

Zapata O, McMillan C (1979) Phenolic acids in seagrasses. Aquat Bot 7:307-317

Zar J (1999) Biostatistical analysis, 4th edn. Prentice-Hall, Upper Saddle River, NJ

Submitted: January 25, 2012; Accepted: July 4, 2012

Proofs received from author(s): September 28, 2012 